\title{
Use of Posters to Promote Speaking Performance among Non-English Majors at Thai Nguyen University of Education, Vietnam
}

\author{
Tran Thi Yen \\ Thai Nguyen University of Education \\ yentt@tnue.edu.vn \\ Tran Thi Minh Hang \\ Thai Nguyen University of Education \\ tranhang18122000@gmail.com
}

DOI: http://doi.org/ 10.36892/ijlls.v3i2.585

\begin{tabular}{ll} 
Received: & Abstract \\
09/05/2021 & English speaking is an important skill for students; however, many English \\
majors at universities in Vietnam in general and non-majors in particular \\
Accepted: & have problems in speaking English. Therefore, the aim of the research is to \\
improve English speaking performance for non-English majors by organizing & activities for students to design posters and speaking based on the posters that \\
& have been designed. The specific objectives are to investigate the current \\
\hline Keywords: & situation of speaking performance among non-English majors at Thai Nguyen \\
speaking, speaking & University of Education as well as organize activities for students to design \\
performance, & posters and speak based on the designed posters, and then evaluate the \\
designing activities & impacts of posters-based speaking activities on the speaking performance of \\
& non-English majors. To conduct the study, a mixed-method research design, \\
& which combines qualitative method and quantitative methods, was used along \\
& with the survey. There were all 20 non-English majors from Maths class at \\
& Thai Nguyen University of Education, who were invited to take part in the \\
research. All of these students were required to take part in the speaking pre- & test and post-test as well as pre-and post-questionnaire about their opinions \\
of using poster designing activities. The results show that designing posters \\
plays a significant role in improving and enhancing English speaking \\
performance for non-English majors. Students' feedback concerning the use of \\
posters designed in speaking classes are, in general, also quite optimistic. \\
Besides, the research proposes some suggestions for minimizing the \\
drawbacks of using posters designing activities to enhance the potentiality of \\
this method and make it more interesting, meaningful and effective.
\end{tabular}

\section{INTRODUCTION}

According to Chaney, A. L., and Burke, T. L. (1998), speaking is one of the language skills which becomes important topic to be taken into consideration when teaching or learning a language due to its influence on the other skills' achievement as well as learners' motivation in getting knowledge of the target language. This skill is the process of creating and sharing meaning in a variety of circumstances through the use of verbal and nonverbal symbols. Speaking is one of the ways to express ideas, feelings, experiences, and knowledge to other people in formal or informal situations. Teaching speaking is an essential aspect of the English learning process. It can increase learners' motivation and make the English language sessions more dynamic and interesting for the learners to attend. 
However, to most people, speaking is the most difficult skill when learning a foreign language. Although everyone knows that the best way to speak a language fluently is to practice speaking as much as possible, not many people can do this. In the learning speaking process, students become frustrated when they lack vocabulary or structures when they need to express their idea; the students may also be worried about making mistakes in their utterance; sometimes they are not interested in the topic. It obligated the teachers to pay more attention to their students' ability and find out an approach, method, strategy, or model that can solve the students' problem to improve their speaking skills.

Having worked with some non-English majors in their first year at Thai Nguyen University of Education, the researchers found that they have some problems with speaking performance. For example, they do not know the way to express their ideas about a topic naturally or how to present about an issue. Although the students sometimes have awareness of the topic and new words related to the topic, they have difficulties making a speech about that and speaking fluently.

There are many ways to improve speaking performance for students, and one of them is through posters. According to Reilly (2007), posters have numerous advantages in the EFL classroom, including the ability to promote oral practice, improve conventional technique by inspiring students, increase student and teacher self-confidence, and facilitate authentic communication. In other words, posters not only help promote students' thinking and creativity abilities but also create a vibrant learning atmosphere in the classroom.

Therefore, this research proposes a solution for students to design posters and speak based on the posters that have been designed. The specific objectives are to investigate the current situation of speaking performance among non-English majors at Thai Nguyen University of Education as well as organize activities for students to design posters and speak based on the designed posters, and then evaluate the impacts of the activities of designing posters on the speaking performance of non-English majors.

\section{LITERATURE REVIEW}

\subsection{Key concepts}

Speaking

Speaking is oral conversation where the participants must negotiate the meaning found in thoughts, emotions, and handle in terms of who is to say what, to whom, and about what, according to Nunan, quoting Bygate $(1987$, p. 4). In other words, speaking is used to make our listener understand our expression. In short, speaking ability refers to a person's ability to communicate his or her thoughts, emotions, or a mental image to others in formal or informal situation.

The researchers believe that speaking is a process of expressing ideas in the spoken language, and it is one of the most challenging aspects of language because it requires basic skills such as pronunciation, fluency, grammar, and vocabulary. H.G.Widdowson (1985:17) also said that vocabulary, frequency of practice, functional grammar, relevant subjects, motivation, self-confidence, and situation are all factors that influence students' speaking ability.

\section{Speaking Performance}

According to Brown (1994), speaking is an interactive process of constructing meaning that involves generating, obtaining, and processing information, and performance refers to the development of actual utterances as a result of certain psychological processes (as cited in Hemerka, 2009, p. 15).

Brown, (2004) stated that the elements of speaking performance are utterance, grammar, vocabulary, fluency, content, and comprehension. Therefore, in this study, the 
researchers stick to five key aspects of speaking performance: accuracy, pronunciation, vocabulary, grammar, and fluency.

Posters

According to the Macmilan Dictionary, a poster is a large printed notice or image that is hung on a wall for decoration, announcement, or advertising. In reality, during the teaching and learning process, the teacher should always try to assist students in expanding their imagination and making it easier for them to express their thoughts. Using posters as teaching aids can be extremely beneficial to the teacher in the classroom, as well as aiding students in visualizing the real object.

According to Ozmen (1990), making a poster is an important part of the learning process. Classroom posters can easily be attributed to long-term memory retention. According to Reilly (2007), posters are used to promote student engagement and provide controlled practice in a specific English framework or definition. According to Sudjana (1989), a poster is a visual representation of pictures that is used as an advertisement, a sign, or to raise people's interest. It is used to draw people's attention to something. Besides, in learning, posters promote students to practice the language in a real-world setting or in situations in which they can share their thoughts, and it encourages them to learn a language by making it easier for them to understand the content and memorize the words they learn from the posters.

\subsection{Previous research}

Many studies have been conducted to investigate the effectiveness of using posters designing activities to enhance students' speaking performance. For instance, Rahmah (2014) carried out a case study at MTs NW Ketangga, a secondary school with a group of 65 students. The results suggested that poster was significantly effective in teaching speaking skill for the seventh graders, especially in presentation skill; however, the research just focused on enhancing presentation skill of students, meanwhile the skill is only an aspect of speaking in general.

Ulva (2018) conducted an action research to improve speaking skills for second graders at MTsN2 Banda Aceh, India. The participants consisted of 35 students. Questionnaires, observation, and interview analysis were utilized to record the progress of students' speaking skills. The research found that posters could make a class situation more alive since the poster media interest students and attract students' attention.

Farisha Andi Baso, Reskiwati Amelia (2014) investigated the improvement of the students' speaking fluency and speaking accuracy through the discussion technique in teaching speaking. The targeted population were 33 students in SMP Pondok Pesantren Darul Aman Gombara Makassar at the eighth grade. The researchers got the information from the students' answers in an oral test in the form of D-test, test of cycle I and test of cycle II. According to the research results, the students became more active and cooperative in learning speaking; therefore, the students' speaking accuracy and speaking fluency achievement were improved significantly.

Chau (2017) proceeded a study using poster making activities as a tool of multiple intelligences for English majored students (Course 2014-2018) from the Foreign Languages Department at Phu Yen University, Vietnam. The participants of the study were 30 secondyear English majored students, who were required to take part in the research because English Speaking - Level B2 is a compulsory subject component in their training curriculum. In this experimental study, they used an English speaking training program with the integration of the poster-making activities, and three English speaking tests conducted before, during and after the intervention to measure and verify the effectiveness of the English speaking training program with the integration of the poster-making activities. The study results showed a significant difference in the statistics at the significance level between the mean scores of the participants from the three speaking tests with better results in the post- 
test. This might be the results of integrating the poster-making activities in the English speaking training program that brought about significant improvement in the students' performance of the English speaking tests.

It can be seen that there are many studies related to posters and the results are universal: posters can help students improve their speaking performance. Therefore, we decided to conduct this research in the context of Thai Nguyen University of Education to build an optimal procedure for creating posters and assessing students' speaking performance based on posters designing activities, and then evaluate its impact on our students' speaking performance.

\section{METHODOLOGY}

\subsection{Research Design}

To conduct the study, the researchers employed mixed methods research design, which combines qualitative method and quantitative methods. First of all, the researchers delivered the pre-questionnaire and the pre-test to the twenty participants to investigate the current situation of speaking performance among non-English majors. Then, the researchers analysed the results of pre-questionnaire and pre-test and found out the weakness in speaking skills of participants. Based on the results of the pre-questionnaire and pre-test, the researchers designed lesson plans and organized poster activities in speaking lessons. This research was also done through classroom observation to assess the learning process and the effects of the activities and the attitude of students. After that, we utilized post-questionnaires to collect feedbacks of students about using posters to promote speaking performance and a post-test to evaluate how posters help students improve their speaking performance. Finally, the researchers collected post-questionnaire and post-test data and analysed them to provide discussions on the processed data.

\subsection{Participants}

Twenty first-year non-English majors at Thai Nguyen University of Education took part in the research. All of these students were required to take part in the speaking pre-test and post-test as well as the pre and post-questionnaire concerning their attitude towards the effectiveness of using posters designing activities.

\subsection{Data collection instruments and procedure Pre-questionnaire}

The aim of the pre-questionnaire is to investigate the students' attitudes about using posters in improving speaking skills, their difficulties and the causes of the difficulties in speaking.

\section{Pre-test}

Prior to the experiment, the participants took part in a speaking lesson. The researchers first gave the learners the way to design a good poster and some suggestions related to the speaking topic such as keywords, main ideas. In addition, the students were supplied several important structures to express their opinions in the speaking process. Based on these, they worked individually and designed a poster, and then they had to record a video of their speaking performance with the designed poster. This video served as the pre-test and was sent to the researchers. Finally, students' videos were assessed according to the Speaking Scoring Rubric designed by the researchers.

\section{Speaking Scoring Rubric}

We have developed a Speaking Scoring Rubric (see Table 1) for grading the students' speaking performance and then perfected it after having consulting experts, who were experienced rators of speaking skills in Thai Nguyen University. Five levels of performance are signified in the rubric: A - Excellent (Score 8.5-10.0), B - Good (Score 7.0-8.4), C - 
Satisfactory (Score 5.5-6.9), D - Poor (Score 4.0-5.4), and F - Failure (Score 0.0-3.9). These levels were identified based on the grading scale of the academic credit system of our university, which is very familiar with the students. For each level, there are five criteria: Fluency and Coherence, Lexical Resource, Grammatical Range and Accuracy, Pronunciation and Poster Design. The descriptors for each criterion were specified based on IELTS Speaking Band Descriptors (public version) and Poster Basics (NYU Libraries).

The test were marked holistically based on the Speaking Scoring Rubric designed by the researchers. Students' speaking performance were assessed separately by two rators (the researchers and a senior English teacher) on each of the five criteria and was marked along ten levels of performance from 1 to 10 . Clear instructions concerning how to employ this rubric were also provided.

\section{Classroom Observation}

The researchers observed the participants continuously from the first speaking lesson with posters designing activities to the final lesson to find the developments in their speaking ability through an observation sheet designed by the researchers. In the first phase, the students' listening to instructions and suggestions of the researchers as well as contributing ideas to the speaking topic were observed and recorded by the researchers. Similarly, in the next phase, we also focused on how the learners divided the task for the members to complete it as well as deciding whether they worked in groups to design their posters effectively or not. Finally, the researchers assessed their presentations and the way they kept contact with other students during the speaking progress through each lesson to find out their improvements in speaking performance.

\section{Post-test}

At the end of the experiment, the students were required to accomplish their poster individually based on some suggestions related to the speaking topic from the researchers in the last speaking lesson. They also had to record a video to speak about their topic based on the designed poster and sent it to the researchers. The speaking videos were evaluated in the same way as in the pre-test.

Table 1. Speaking Scoring Rubric

\begin{tabular}{|c|c|c|c|c|c|}
\hline Score bevel & Fluency and coherence & Lesical resource & $\begin{array}{l}\text { Gramimatical range } \\
\text { and accuracy }\end{array}$ & Prosuneiation & Poster Desigs \\
\hline $\begin{array}{c}\text { A } \\
\text { Exceilient } \\
\text { (8.5-10) }\end{array}$ & 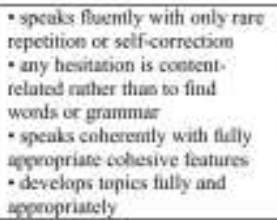 & 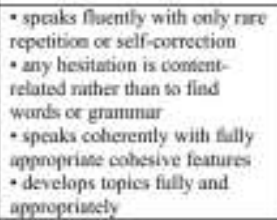 & 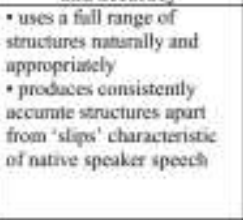 & $\begin{array}{l}\text { - uses a full range of } \\
\text { promiaciation features with } \\
\text { precision asd subelaty } \\
\text { - sastains flexible use of } \\
\text { features throughoot } \\
\text { - is effortess to anderstand }\end{array}$ & 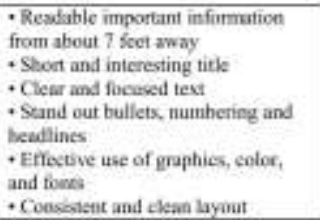 \\
\hline$\underset{\substack{\text { Geed } \\
(7.8-8,4)}}{\text { at }}$ & 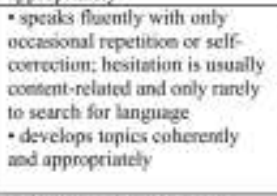 & $\begin{array}{l}\text { - uses a wỉde vocabulary } \\
\text { resource readily and texibly to } \\
\text { comvey precise meaning } \\
\text { - uses less common and } \\
\text { idsomatic vocabulary skilfully, } \\
\text { with occisional imaccuracies } \\
\text { - uses paraphtrase effectively as } \\
\text { required }\end{array}$ & $\begin{array}{l}\text { - uses a wide ringe of } \\
\text { structures flexibly } \\
\text { - finquently produces } \\
\text { emur-finte sentences. } \\
\text { though snme grammatical } \\
\text { intistakes pessist }\end{array}$ & $\begin{array}{l}\text { - uses a wide range of } \\
\text { promuociation feathares } \\
\text { - sustains flexible use of } \\
\text { features, with anly occasional } \\
\text { lapses } \\
\text { - is casy to understand } \\
\text { throughouat }\end{array}$ & 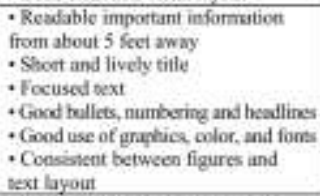 \\
\hline $\begin{array}{c}C \\
\text { Satisfactery } \\
(5.5-6.9)\end{array}$ & 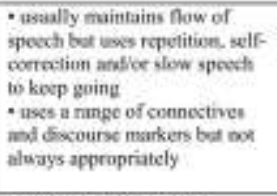 & 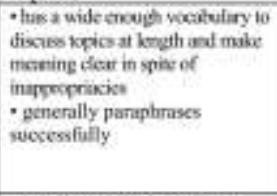 & 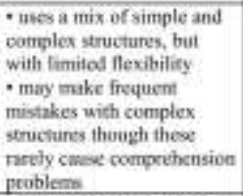 & 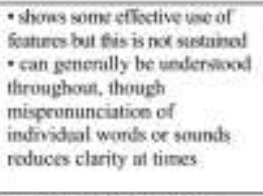 & 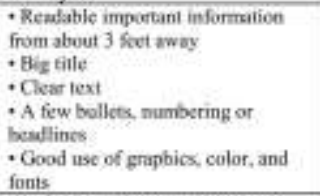 \\
\hline$\underset{\substack{\text { Poor } \\
(+0-5,-4)}}{\text { D }}$ & 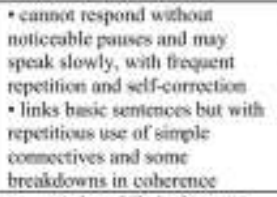 & 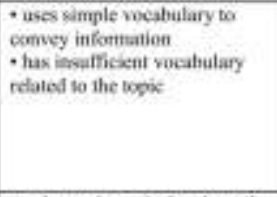 & 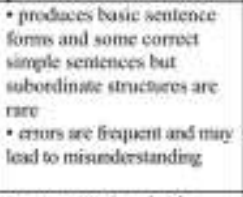 & 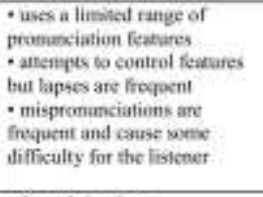 & 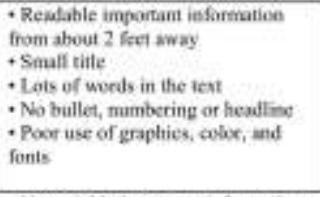 \\
\hline $\begin{array}{c}F \\
\text { Failure } \\
(0.0-3.9)\end{array}$ & $\begin{array}{l}\text { - pauser lengthily before mast } \\
\text { wonds } \\
\text { - little costminication possible }\end{array}$ & $\begin{array}{l}\text { - anly produces solited woends } \\
\text { or menorised unterinces }\end{array}$ & $\begin{array}{l}\text { - camnot prodice basic } \\
\text { sentessce firms }\end{array}$ & $\begin{array}{l}\text { - Speect as often } \\
\text { unintelligibile }\end{array}$ & 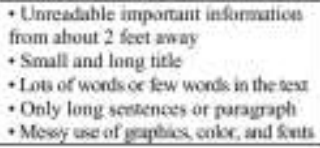 \\
\hline
\end{tabular}


The pre-post test design required the researchers to collect data about the students' level of speaking performance before the research took place, and then to collect the same data at the end of the research period. In this study, the pre-post test design allows the researchers to evaluate the impact of posters designing activities on students' speaking performance by comparing the differences between the pre-test and post-test results.

\section{Post-questionnaire}

The researchers designed the questionnaire based on two kinds of questions: openended questions and close-ended questions. Based on their feedback, the questionnaire was designed to gather the participants' feedback relating to posters designing activities, including such aspects as procedure/steps, benefits, disadvantages, attitudes of participants and possible solutions to enhance the effectiveness of using posters in speaking classes.

\section{RESEARCH RESULTS ANALYSIS AND DISCUSSION}

\subsection{Results of the Pre-questionnaire}

The pre-questionnaire results show that because all students have studied English for a long time, they have a good environment to develop English speaking skills. Furthermore, they were aware of the importance of English in their future, which is considered a great motivator for them to be active and disciplined in their study of the foreign language. Besides, the participants exhibited their positive attitude toward using posters designing activities in speaking lessons though they had few opportunities to participate in the activities when they were in high schools. As a result, the majority of them believe they are poor communicators for different reasons such as a lack of vocabulary, fear of making grammar mistakes when speaking English, etc.

\subsection{The impacts of posters designing activities on students' speaking performance}

In the pre- test, the students had to record a video to present about their posters designed by themselves. The speaking topic was about a modern mean of transportation used in the future. The researcher saw that, the students' speaking ability is quite poor. In addition, some of them could not pronounce correctly simple words such as name, sky, class, control, choose, data, touch, drive, etc. Although the students prepared their speech before recording, they did not speak fluently; their grammar was also not good, and they did not have enough vocabulary to express their ideas. Some of the students' mistakes are listed in the table below:

Table 2. Frequent mistakes committed by the participants in the speaking pre-test

\begin{tabular}{|c|c|c|}
\hline \multirow[t]{2}{*}{ Student } & \multicolumn{2}{|r|}{ Mistakes } \\
\hline & Pre-test & Post-test \\
\hline S1 & $\begin{array}{l}\text { F: pauses lengthily before most words } \\
\text { L: only produces isolated words or } \\
\text { memorized utterances } \\
\text { G: produces basic sentence (People can } \\
\text { fly, etc.) } \\
\text { P: speak unintelligibly (vehicles, data, } \\
\text { future, plan, characteristic, etc.) } \\
\text { PD: Messy use of graphics, color, and } \\
\text { fonts } \\
\text { SCORE: } 3.0\end{array}$ & $\begin{array}{l}\text { F: maintains flow of speech but uses repetition; uses a range of } \\
\text { connectives but not always appropriately } \\
\text { L: has a wide enough vocabulary in spite of inappropriacies; } \\
\text { generally paraphrases successfully } \\
\text { G: uses a mix of simple and complex structures, but with limited } \\
\text { flexibility; may make frequent mistakes with complex structures } \\
\text { (A student express her feeling in the moment that had to leave my } \\
\text { school, etc.) } \\
\text { P: shows some effective use of features but this is not sustained; } \\
\text { can generally be understood throughout, though mispronunciation } \\
\text { of individual words or sounds reduces clarity at times } \\
\text { (memorable, cried, heart, etc.) } \\
\text { PD: Good use of graphics, color, and fonts; big title; clear text } \\
\text { SCORE: } 6.5\end{array}$ \\
\hline S2 & $\begin{array}{l}\text { F: pauses lengthily before most words } \\
\text { L: only produces isolated words or } \\
\text { memorised utterances } \\
\text { G: produces basic sentence forms (A car } \\
\text { but many ways too control it; You can fly } \\
\text { in the air, etc.) } \\
\text { P: speak unintelligibly (name, class, }\end{array}$ & $\begin{array}{l}\text { F: maintains flow of speech but uses repetition; uses a range of } \\
\text { connectives but not always appropriately } \\
\text { L: has a wide enough vocabulary in spite of inappropriacies; } \\
\text { generally paraphrases successfully } \\
\text { G: uses a mix of simple and complex structures, but with limited } \\
\text { flexibility; may make frequent mistakes with complex structures } \\
\text { (While my mother was cooking the dinner meal, I was looking }\end{array}$ \\
\hline
\end{tabular}




\begin{tabular}{|c|c|c|}
\hline & $\begin{array}{l}\text { hobbies, control, choose, data, toilet, } \\
\text { useful, air, etc.) } \\
\text { PD: Messy use of graphics, color, and } \\
\text { fonts } \\
\text { SCORE: } 3.0\end{array}$ & $\begin{array}{l}\text { after my young sister, etc.) } \\
\text { P: shows some effective use of features but this is not sustained; } \\
\text { can generally be understood throughout, though mispronunciation } \\
\text { of individual words or sounds reduces clarity at times (house, } \\
\text { childhood, scaried, etc.) } \\
\text { PD: Good use of graphics, color, and fonts; big title; clear text } \\
\text { SCORE: } 6.5\end{array}$ \\
\hline S3 & $\begin{array}{l}\text { F: pauses lengthily before most words } \\
\text { L: only produces isolated words or } \\
\text { memorised utterances } \\
\text { G: produces basic sentence forms (I want } \\
\text { to introduce you, etc.) } \\
\text { P: speak unintelligibly (everybody, large, } \\
\text { company, country, technique, believe, } \\
\text { etc.) } \\
\text { PD: Messy use of graphics, color, and } \\
\text { fonts } \\
\text { SCORE: } 3.0\end{array}$ & $\begin{array}{l}\text { F: speaks fluently with only occasional repetition or self- } \\
\text { correction; hesitation is usually content-related and only rarely to } \\
\text { search for language } \\
\text { L: uses a wide vocabulary resource readily and flexibly; uses less } \\
\text { common and idiomatic vocabulary skilfully, with occasional } \\
\text { inaccuracies } \\
\text { G: uses a wide range of structures flexibly (When coming to Ba } \\
\text { Vi, intead of hiring a car, I decided to go for walk, etc.) } \\
\text { P: uses a wide range of pronunciation features; is easy to } \\
\text { understand throughout (roads, impressions, experiences, etc.) } \\
\text { PD: Consistent between figures and text layout } \\
\text { SCORE: } 7.5\end{array}$ \\
\hline $\mathrm{S} 4$ & $\begin{array}{l}\text { F: pauses lengthily before most words } \\
\text { L: only produces isolated words or } \\
\text { memorised utterances } \\
\text { G: produces basic sentence forms and } \\
\text { some correct simple sentences (The } \\
\text { modern car has a special key, etc.) } \\
\text { P: speak unintelligibly (next, touch, } \\
\text { stealing, expected, fly, will, nature, } \\
\text { modern, etc.) } \\
\text { PD: Correct use of graphics, color, and } \\
\text { fonts } \\
\text { SCORE: } 3.5\end{array}$ & $\begin{array}{l}\text { F: speaks fluently with only occasional repetition or self- } \\
\text { correction; hesitation is usually content-related and only rarely to } \\
\text { search for language } \\
\text { L: uses a wide vocabulary resource readily and flexibly; uses less } \\
\text { common and idiomatic vocabulary skilfully, with occasional } \\
\text { inaccuracies } \\
\text { G: uses a wide range of structures flexibly (That day was very } \\
\text { nice when the flowers around my house blossom out brilliantly, } \\
\text { etc.) etc.) } \\
\text { P: uses a wide range of pronunciation features; is easy to } \\
\text { understand throughout (beautiful, dark, wet, etc.) } \\
\text { PD: Consistent between figures and text layout } \\
\text { SCORE:7.5 }\end{array}$ \\
\hline S5 & $\begin{array}{l}\text { F: pauses lengthily before most words } \\
\text { L: only produces isolated words or } \\
\text { memorised utterances } \\
\text { G: produces basic sentence forms (I want } \\
\text { design, etc.) } \\
\text { P: speak unintelligibly (name, organize, } \\
\text { material, nature, dangerous, face, future, } \\
\text { etc.) } \\
\text { PD: Messy use of graphics, color, and } \\
\text { fonts } \\
\text { SCORE: } 3.0\end{array}$ & $\begin{array}{l}\text { F: maintains flow of speech but uses repetition, self-correction } \\
\text { and/or slow speech to keep going } \\
\text { L: has a wide enough vocabulary in spite of inappropriacies } \\
\text { G: uses a mix of simple and complex structures, but with limited } \\
\text { flexibility (When I entered the entrance hall, I feel very excited, } \\
\text { etc.) } \\
\text { P: can generally be understood throughout, though } \\
\text { mispronunciation of individual words or sounds reduces clarity at } \\
\text { times (gathered, surprised, etc.) } \\
\text { PD: Good use of graphics, color, and fonts } \\
\text { SCORE: } 6.0\end{array}$ \\
\hline S6 & $\begin{array}{l}\text { F: speak slowly with frequent repetition } \\
\text { and self-correction } \\
\text { L: uses simple vocabulary to convey } \\
\text { personal information } \\
\text { G: produces basic sentence forms and } \\
\text { some correct simple sentences but } \\
\text { subordinate structures are rare; errors are } \\
\text { frequent and may lead to } \\
\text { misunderstanding (The first aim of SAC } \\
\text { is protecting, etc.) } \\
\text { P: mispronunciations are frequent and } \\
\text { cause some difficulty for the listener } \\
\text { (large, space, touch, drive, etc.) } \\
\text { PD: Poor use of graphics, color, and } \\
\text { fonts } \\
\text { SCORE: } 4.5\end{array}$ & $\begin{array}{l}\text { F: speaks fluently with only occasional repetition or self- } \\
\text { correction; hesitation is usually content-related and only rarely to } \\
\text { search for language; develops topics coherently and appropriately } \\
\text { L: uses a wide vocabulary resource readily and flexibly; uses less } \\
\text { common and idiomatic vocabulary skilfully, with occasional } \\
\text { inaccuracies; uses paraphrase effectively } \\
\text { G: uses a wide range of structures flexibly; frequently produces } \\
\text { error-free sentences, though some grammatical mistakes persist } \\
\text { (This is the first time I have got sick, It was the most terrible time } \\
\text { in my life until now, etc.) } \\
\text { P: uses a wide range of pronunciation features; sustains flexible } \\
\text { use of features with only occasional lapses, is easy to understand } \\
\text { throughout (exercises, fortunately, etc.) } \\
\text { PD: Good use of graphics, color, and fonts; Consistent between } \\
\text { figures and text layout } \\
\text { SCORE: } 8.0\end{array}$ \\
\hline S7 & $\begin{array}{l}\text { F: pauses lengthily before most words } \\
\text { L: only produces isolated words or } \\
\text { memorised utterances } \\
\text { G: produces basic sentence forms (You } \\
\text { can control it by wind energy, solar } \\
\text { energy, water energy, etc.) } \\
\text { P: speak unintelligibly (name, organize, } \\
\text { control, energy, normal, etc.) } \\
\text { PD: Messy use of graphics, color, and }\end{array}$ & $\begin{array}{l}\text { F: pauses lengthily before most words } \\
\text { L: has a wide enough vocabulary in spite of inappropriacies; } \\
\text { generally paraphrases successfully } \\
\text { G: uses a mix of simple and complex structures, but with limited } \\
\text { flexibility; may make frequent mistakes with complex structures } \\
\text { (From my jouney, I had a chance to learn many important lessons } \\
\text { that I never could learn at school..., etc.) } \\
\text { P: shows some effective use of features but this is not sustained; } \\
\text { can generally be understood throughout, though mispronunciation }\end{array}$ \\
\hline
\end{tabular}




\begin{tabular}{|c|c|c|}
\hline & $\begin{array}{l}\text { fonts } \\
\text { SCORE: } 3.0\end{array}$ & $\begin{array}{l}\text { of individual words or sounds reduces clarity at times } \\
\text { PD: Good use of graphics, color, and fonts; big title; clear text } \\
\text { SCORE: } 6.5\end{array}$ \\
\hline S8 & $\begin{array}{l}\text { F: speak slowly, with frequent repetition } \\
\text { L: uses simple vocabulary to convey } \\
\text { personal information } \\
\text { G: produces basic sentence forms and } \\
\text { some correct simple sentences but } \\
\text { subordinate structures are rare; errors are } \\
\text { frequent and may lead to } \\
\text { misunderstanding (It has advantage of } \\
\text { small size, etc.) } \\
\text { P: mispronunciations are frequent and } \\
\text { cause some difficulty for the listener } \\
\text { (especially, resource, etc.) } \\
\text { PD: Small title; lots of words in the text } \\
\text { SCORE: } 5.0\end{array}$ & $\begin{array}{l}\text { F: speaks fluently with only occasional repetition or self- } \\
\text { correction; hesitation is usually content-related and only rarely to } \\
\text { search for language } \\
\text { L: uses a wide vocabulary resource readily and flexibly; uses less } \\
\text { common and idiomatic vocabulary skilfully, with occasional } \\
\text { inaccuracies } \\
\text { G: uses a wide range of structures flexibly (Going on holiday out } \\
\text { of season when everybody else is working can save you a lot of } \\
\text { money etc.) } \\
\text { P: uses a wide range of pronunciation features; is easy to } \\
\text { understand throughout (sunbathe, beach, etc.) } \\
\text { PD: Consistent between figures and text layout } \\
\text { SCORE: } 7.5\end{array}$ \\
\hline S9 & $\begin{array}{l}\text { F: maintains flow of speech but uses } \\
\text { repetition, self-correction and/or slow } \\
\text { speech to keep going } \\
\text { L: has a wide enough vocabulary in spite } \\
\text { of inappropriacies } \\
\text { G: uses a mix of simple and complex } \\
\text { structures, but with limited flexibility } \\
\text { (The Tuk Tuk doesn't disappointed you; } \\
\text { Many color such blue, green, etc.) } \\
\text { P: can generally be understood } \\
\text { throughout, though mispronunciation of } \\
\text { individual words or sounds reduces } \\
\text { clarity at times (called, touch, etc.) } \\
\text { PD: Good use of graphics, color, and } \\
\text { fonts } \\
\text { SCORE: } 6.0\end{array}$ & $\begin{array}{l}\text { F: speaks fluently with only occasional repetition or self- } \\
\text { correction; hesitation is usually content-related and only rarely to } \\
\text { search for language; develops topics coherently and appropriately } \\
\text { L: uses a wide vocabulary resource readily and flexibly; uses less } \\
\text { common and idiomatic vocabulary skilfully, with occasional } \\
\text { inaccuracies; uses paraphrase effectively } \\
\text { G: uses a wide range of structures flexibly; frequently produces } \\
\text { error-free sentences, though some grammatical mistakes persist } \\
\text { (While I waited at the train station, Hoa realized that the train } \\
\text { was late.etc.) } \\
\text { P: uses a wide range of pronunciation features; sustains flexible } \\
\text { use of features with only occasional lapses, is easy to understand } \\
\text { throughout (late, hour, worry, etc.) } \\
\text { PD: Good use of graphics, color, and fonts; Consistent between } \\
\text { figures and text layout } \\
\text { SCORE: } 8.0\end{array}$ \\
\hline $\mathrm{S} 10$ & $\begin{array}{l}\text { F: speak slowly, with frequent repetition } \\
\text { L: uses simple vocabulary to convey } \\
\text { personal information } \\
\text { G: produces basic sentence forms and } \\
\text { some correct simple sentences but } \\
\text { subordinate structures are rare; errors are } \\
\text { frequent and may lead to } \\
\text { misunderstanding (Like is the name, this } \\
\text { product can ride on the road and go on } \\
\text { the water, etc.) } \\
\text { P: mispronunciations are frequent and } \\
\text { cause some difficulty for the listener } \\
\text { (called, because, suitable, etc.) } \\
\text { PD: Small title; lots of words in the text } \\
\text { SCORE: } 5.0\end{array}$ & $\begin{array}{l}\text { F: speaks fluently with only occasional repetition or self- } \\
\text { correction; hesitation is usually content-related and only rarely to } \\
\text { search for language } \\
\text { L: uses a wide vocabulary resource readily and flexibly; uses less } \\
\text { common and idiomatic vocabulary skilfully, with occasional } \\
\text { inaccuracies } \\
\text { G: uses a wide range of structures flexibly (We imagine how we } \\
\text { appear to those around us., etc.) } \\
\text { P: uses a wide range of pronunciation features; is easy to } \\
\text { understand throughout (ugly, wrinkle, etc.) } \\
\text { PD: Consistent between figures and text layout } \\
\text { SCORE: } 7.5\end{array}$ \\
\hline $\mathrm{S} 11$ & $\begin{array}{l}\text { F: speak slowly with frequent repetition } \\
\text { and self-correction } \\
\text { L: uses simple vocabulary to convey } \\
\text { personal information } \\
\text { G: produces basic sentence forms and } \\
\text { some correct simple sentences but } \\
\text { subordinate structures are rare; errors are } \\
\text { frequent and may lead to } \\
\text { misunderstanding (The aim of product } \\
\text { protecting the environment and save } \\
\text { money, etc.) } \\
\text { P: mispronunciations are frequent and } \\
\text { cause some difficulty for the listener } \\
\text { (natural, electricity, etc.) } \\
\text { PD: Poor use of graphics, color, and } \\
\text { fonts } \\
\text { SCORE: } 4.5\end{array}$ & $\begin{array}{l}\text { F: speaks fluently with only occasional repetition or self- } \\
\text { correction } \\
\text { L: uses a wide vocabulary resource } \\
\text { G: uses a wide range of structures flexibly (At that time, I was } \\
\text { really tired, but on a positive outlook, everything was new that } \\
\text { made me forget all of my previous difficulties, etc.) } \\
\text { P: is easy to understand throughout (sandals, mud, impression, } \\
\text { etc.) } \\
\text { PD: Good use of graphics, color, and fonts; Short and lively title } \\
\text { SCORE: } 7.0\end{array}$ \\
\hline
\end{tabular}




\begin{tabular}{|c|c|c|}
\hline $\mathrm{S} 12$ & $\begin{array}{l}\text { F: speak slowly with frequent repetition } \\
\text { and self-correction } \\
\text { L: uses simple vocabulary to convey } \\
\text { personal information } \\
\text { G: produces basic sentence forms and } \\
\text { some correct simple sentences but } \\
\text { subordinate structures are rare; errors are } \\
\text { frequent and may lead to } \\
\text { misunderstanding (It has wing and it fly } \\
\text { in the sky and it, etc.) } \\
\text { P: mispronunciations are frequent and } \\
\text { cause some difficulty for the listener } \\
\text { (vehicle, environment, etc.) } \\
\text { PD: Poor use of graphics, color, and } \\
\text { fonts } \\
\text { SCORE: } 4.5\end{array}$ & $\begin{array}{l}\text { F: maintains flow of speech but uses repetition, self-correction } \\
\text { and/or slow speech to keep going } \\
\text { L: has a wide enough vocabulary in spite of inappropriacies } \\
\text { G: uses a mix of simple and complex structures, but with limited } \\
\text { flexibility (The movie, though very long, was still very enjoyable. } \\
\text { etc.) } \\
\text { P: can generally be understood throughout, though } \\
\text { mispronunciation of individual words or sounds reduces clarity at } \\
\text { times (called, delight, etc.) } \\
\text { PD: Good use of graphics, color, and fonts; Consistent between } \\
\text { figures and text layout } \\
\text { SCORE: } 6.0\end{array}$ \\
\hline $\mathrm{S} 13$ & $\begin{array}{l}\text { F: maintains flow of speech but uses } \\
\text { repetition, self-correction and/or slow } \\
\text { speech to keep going } \\
\text { L: has a wide enough vocabulary in spite } \\
\text { of inappropriacies } \\
\text { G: uses a mix of simple and complex } \\
\text { structures, but with limited flexibility } \\
\text { (Because they are friendly and we can } \\
\text { avoid, etc.) } \\
\text { P: can generally be understood } \\
\text { throughout, though mispronunciation of } \\
\text { individual words or sounds reduces } \\
\text { clarity at times (vehicle, battery, etc.) } \\
\text { PD: Good use of graphics, color, and } \\
\text { fonts } \\
\text { SCORE: } 6.0\end{array}$ & $\begin{array}{l}\text { F: speaks fluently with only occasional repetition or self- } \\
\text { correction; hesitation is usually content-related and only rarely to } \\
\text { search for language; develops topics coherently and appropriately } \\
\text { L: uses a wide vocabulary resource readily and flexibly; uses less } \\
\text { common and idiomatic vocabulary skilfully, with occasional } \\
\text { inaccuracies; uses paraphrase effectively } \\
\text { G: uses a wide range of structures flexibly; frequently produces } \\
\text { error-free sentences, though some grammatical mistakes persist } \\
\text { (Because Mary and Samantha arrived at the bus station before } \\
\text { noon, I did not see them at the station, etc.) } \\
\text { P: uses a wide range of pronunciation features; sustains flexible } \\
\text { use of features with only occasional lapses, is easy to understand } \\
\text { throughout (luckily, impossible, etc.) } \\
\text { PD: Good use of graphics, color, and fonts; Consistent between } \\
\text { figures and text layout } \\
\text { SCORE: } 8.0\end{array}$ \\
\hline S14 & $\begin{array}{l}\text { F: speak slowly with frequent repetition } \\
\text { L: uses simple vocabulary to convey } \\
\text { personal information } \\
\text { G: produces basic sentence forms and } \\
\text { some correct simple sentences but } \\
\text { subordinate structures are rare; errors are } \\
\text { frequent and may lead to } \\
\text { misunderstanding (from planet to planet, } \\
\text { etc.) } \\
\text { P: mispronunciations are frequent and } \\
\text { cause some difficulty for the listener } \\
\text { (distance, space, explore, etc.) } \\
\text { PD: Small title; lots of words in the text } \\
\text { SCORE: } 5.0\end{array}$ & $\begin{array}{l}\text { F: speaks fluently with only occasional repetition or self- } \\
\text { correction; hesitation is usually content-related and only rarely to } \\
\text { search for language; develops topics coherently and appropriately } \\
\text { L: uses a wide vocabulary resource readily and flexibly; uses less } \\
\text { common and idiomatic vocabulary skilfully, with occasional } \\
\text { inaccuracies; uses paraphrase effectively } \\
\text { G: uses a wide range of structures flexibly; frequently produces } \\
\text { error-free sentences, though some grammatical mistakes persist } \\
\text { (Tuyen realised that I couldn't go home because of not having an } \\
\text { umbrella, so she gave me her raincoat, etc.) } \\
\text { P: uses a wide range of pronunciation features; sustains flexible } \\
\text { use of features with only occasional lapses, is easy to understand } \\
\text { throughout (chalk, rained, etc.) } \\
\text { PD: Good use of graphics, color, and fonts; Consistent between } \\
\text { figures and text layout } \\
\text { SCORE: } 8.0\end{array}$ \\
\hline $\mathrm{S} 15$ & $\begin{array}{l}\text { F: pauses lengthily before most words } \\
\text { L: only produces isolated words or } \\
\text { memorised utterances } \\
\text { G: produces basic sentence forms } \\
\text { (contact with our complain, etc.) } \\
\text { P: speak unintelligibly (also, right now, } \\
\text { company, touch, etc.) } \\
\text { PD: Messy use of graphics, color, and } \\
\text { fonts } \\
\text { SCORE: } 3.0\end{array}$ & $\begin{array}{l}\text { F: speaks fluently with only occasional repetition or self- } \\
\text { correction } \\
\text { L: uses a wide vocabulary resource } \\
\text { G: uses a wide range of structures flexibly (I would like to know } \\
\text { how my mother succeed.etc.) } \\
\text { P: is easy to understand throughout (intelligent, gentle etc.) } \\
\text { PD: Good use of graphics, color, and fonts; Short and lively title } \\
\text { SCORE: } 7.0\end{array}$ \\
\hline S16 & $\begin{array}{l}\text { F: pauses lengthily before most words } \\
\text { L: only produces isolated words or } \\
\text { memorised utterances } \\
\text { G: produces basic sentence forms (Flying } \\
\text { car can fly on the crowd while flying into } \\
\text { the sky, etc.) } \\
\text { P: speak unintelligibly (guy, year old, } \\
\text { but, future, vehicle, sky, etc.) } \\
\text { PD: Messy use of graphics, color, and } \\
\text { fonts }\end{array}$ & $\begin{array}{l}\text { F: pauses lengthily before most words } \\
\text { L: has a wide enough vocabulary in spite of inappropriacies; } \\
\text { generally paraphrases successfully } \\
\text { G: uses a mix of simple and complex structures, but with limited } \\
\text { flexibility; may make frequent mistakes with complex structures } \\
\text { (I sang some songs and dance around the fire as well as share } \\
\text { some important things to make people understand more about me } \\
\text { and the others etc.) } \\
\text { P: shows some effective use of features but this is not sustained; } \\
\text { can generally be understood throughout, though mispronunciation }\end{array}$ \\
\hline
\end{tabular}




\begin{tabular}{|c|c|c|}
\hline & SCORE: 3.0 & $\begin{array}{l}\text { of individual words or sounds reduces clarity at times (ourselves, } \\
\text { danced, vacation, etc.) } \\
\text { PD: Good use of graphics, color, and fonts; big title; clear text } \\
\text { SCORE: } 6.5\end{array}$ \\
\hline S17 & $\begin{array}{l}\text { F: pauses lengthily before most words } \\
\text { L: only produces isolated words or } \\
\text { memorised utterances } \\
\text { G: produces basic sentence forms (In } \\
\text { recent year, pollution is serious; It has } \\
\text { wing it is help to reduce environment, } \\
\text { etc.) } \\
\text { P: speak unintelligibly (environment, } \\
\text { face, serious, etc.) } \\
\text { PD: Messy use of graphics, color, and } \\
\text { fonts } \\
\text { SCORE: } 3.0\end{array}$ & $\begin{array}{l}\text { F: speaks fluently with only occasional repetition or self- } \\
\text { correction; hesitation is usually content-related and only rarely to } \\
\text { search for language } \\
\text { L: uses a wide vocabulary resource readily and flexibly; uses less } \\
\text { common and idiomatic vocabulary skilfully, with occasional } \\
\text { inaccuracies } \\
\text { G: uses a wide range of structures flexibly (It is so hot that we } \\
\text { cannot go out without an umbrella, etc.) } \\
\text { P: uses a wide range of pronunciation features; is easy to } \\
\text { understand throughout (cats and dogs, water, etc.) } \\
\text { PD: Consistent between figures and text layout } \\
\text { SCORE: } 7.5\end{array}$ \\
\hline S18 & $\begin{array}{l}\text { F: pauses lengthily before most words } \\
\text { L: only produces isolated words or } \\
\text { memorised utterances } \\
\text { G: produces basic sentence forms } \\
\text { (People instead of talking bus or private } \\
\text { car, they will going to couple car station, } \\
\text { etc.) } \\
\text { P: speak unintelligibly (each, all, private, } \\
\text { instead, etc.) } \\
\text { PD: Messy use of graphics, color, and } \\
\text { fonts } \\
\text { SCORE: } 3.0\end{array}$ & $\begin{array}{l}\text { F: speaks fluently with only occasional repetition or self- } \\
\text { correction; hesitation is usually content-related and only rarely to } \\
\text { search for language } \\
\text { L: uses a wide vocabulary resource readily and flexibly; uses less } \\
\text { common and idiomatic vocabulary skilfully, with occasional } \\
\text { inaccuracies } \\
\text { G: uses a wide range of structures flexibly (Although I like } \\
\text { traveling, I haven't had the time to go recently, and I also haven't } \\
\text { found anyone to go with me.etc.) } \\
\text { P: uses a wide range of pronunciation features; is easy to } \\
\text { understand throughout (scenery, attractive, maverlous, etc.) } \\
\text { PD: Consistent between figures and text layout } \\
\text { SCORE: } 7.5\end{array}$ \\
\hline S19 & $\begin{array}{l}\text { F: pauses lengthily before most words } \\
\text { L: only produces isolated words or } \\
\text { memorised utterances } \\
\text { G: produces basic sentence forms (I } \\
\text { decide it to be solar and wind; blue print, } \\
\text { etc.) } \\
\text { P: speak unintelligibly (vehicle, face, } \\
\text { will, convenient, etc.) } \\
\text { PD: Messy use of graphics, color, and } \\
\text { fonts } \\
\text { SCORE: } 3.0\end{array}$ & $\begin{array}{l}\text { F: pauses lengthily before most words } \\
\text { L: has a wide enough vocabulary in spite of inappropriacies; } \\
\text { generally paraphrases successfully } \\
\text { G: uses a mix of simple and complex structures, but with limited } \\
\text { flexibility; may make frequent mistakes with complex structures } \\
\text { (The weather was cold and wet, yet we enjoyed it very much., etc.) } \\
\text { P: shows some effective use of features but this is not sustained; } \\
\text { can generally be understood throughout, though mispronunciation } \\
\text { of individual words or sounds reduces clarity at times (climb, } \\
\text { jouney, atmosphere, etc.) } \\
\text { PD: Good use of graphics, color, and fonts; big title; clear text } \\
\text { SCORE: } 6.5\end{array}$ \\
\hline S20 & $\begin{array}{l}\text { F: pauses lengthily before most words } \\
\text { L: only produces isolated words or } \\
\text { memorised utterances } \\
\text { G: produces basic sentence forms (It's } \\
\text { solar panel on the roof, a battery to store } \\
\text { energy in the back of the car; It costs for } \\
\text { thousand dollars, etc.) } \\
\text { P: speak unintelligibly (called, noise, } \\
\text { large, store, battery, suitable, etc.) } \\
\text { PD: Messy use of graphics, color, and } \\
\text { fonts } \\
\text { SCORE: } 3.0\end{array}$ & $\begin{array}{l}\text { F: speaks fluently with only occasional repetition or self- } \\
\text { correction; hesitation is usually content-related and only rarely to } \\
\text { search for language } \\
\text { L: uses a wide vocabulary resource readily and flexibly; uses less } \\
\text { common and idiomatic vocabulary skilfully, with occasional } \\
\text { inaccuracies } \\
\text { G: uses a wide range of structures flexibly (What I wanted above } \\
\text { everything else in the whole world was a young sister.etc.) } \\
\text { P: uses a wide range of pronunciation features; is easy to } \\
\text { understand throughout (take care, ill, medicine, etc.) } \\
\text { PD: Consistent between figures and text layout } \\
\text { SCORE: } 7.5\end{array}$ \\
\hline
\end{tabular}

(F: Fluency and coherence; L: Lexical resource; G: Grammatical range and accuracy; P: Pronunciation; PD: Poster Design)

However, in the post-test, most of these mistakes have been overcome. In order to evaluate the impacts of posters on students' speaking performance, we compared the students' speaking scores in the pre-test and post-test. The following chart illustrates the scores in the speaking pre-test and post-test gained by the students. 


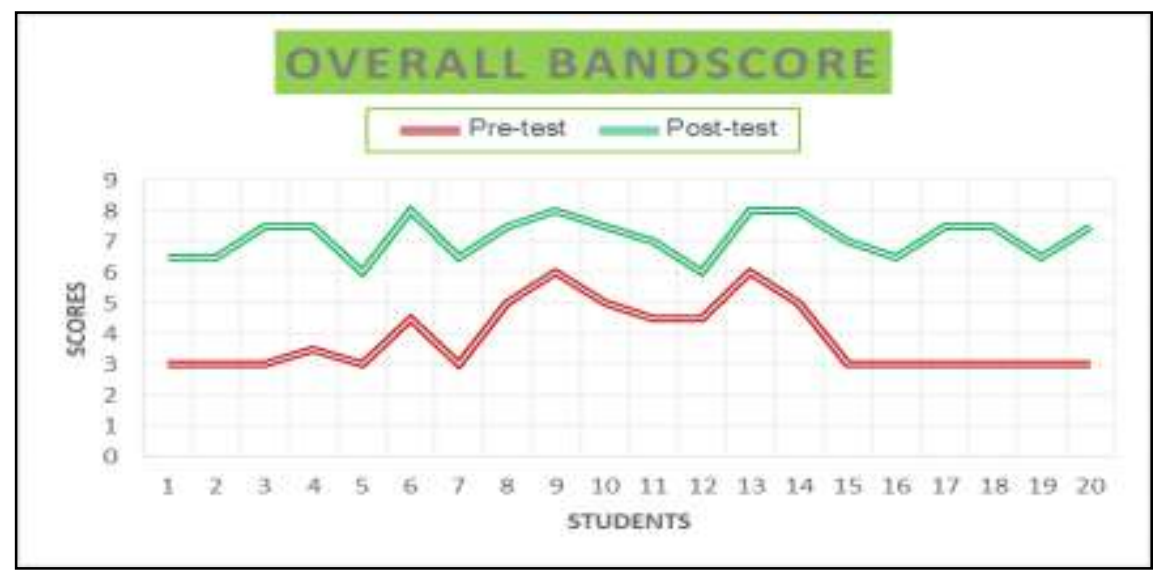

Figure 1. Speaking pre and post-test scores of students

It can be clearly seen from figure 1 that the pre-test scores were relatively low, primarily ranging from 3.0 to 6.0 . The number of students who got mark 3.0 comprised of $55 \%$ of the students while only $15 \%$ and $10 \%$ of the students could gain mark 5.0 and 6.0 , respectively. However, after applying posters designing activities in speaking lessons, their speaking performance has improved remarkably. It is visible from the figure that the post-test scores are mainly in the range of 7.0 to 8.0. The post-test scores witnessed a dramatic rise compared to the results in the pre-test. $20 \%$ of the students got mark 8.0 and $35 \%$ could gain mark 7.5, which was impossible in the pre-test. It is noticeable that mark 6.0 was the highest score in the pre-test; however, it was the lowest score in the post-test.

Table 3. Average Scores in the Speaking Pre-test and Post-test

\begin{tabular}{|c|c|}
\hline Pre-test & 4.0 \\
\hline Post-test & 7.0 \\
\hline
\end{tabular}

It can be seen from the table that there was a considerable increase in the average scores in students' post-test results. While assessing the students' pre-test speaking performance, the researchers found that it was very hard for students to pronounce the words correctly or keep their speaking fluency. Moreover, they made a lot of grammatical mistakes during the speech as well as repeated the same words many times. Nevertheless, after they took part in poster designing activities as well as gained some useful advices and instructions from the researchers, they had more motivation to speak properly. Specifically, the students gathered more vocabulary, structures and ideas to present. Besides, the learners also tended to become more confident and know the way to keep their enthusiasm and attract other students' attention by using gestures or giving extra questions in the speaking progress. Therefore, they got much higher average score at 7.0 in the post-test, compared to only 4.0 in the pre-test.

4.3. The impact of posters designing activities on different aspects of students' speaking performance

Students' speaking performance was assessed according to the Speaking Scoring Rubric focusing on five criteria: Fluency and Coherence, Lexical Resource, Grammatical Range and Accuracy, Pronunciation and Poster Design.

Table 4. Average scores according to the Speaking criteria

\begin{tabular}{|l|c|c|c|c|c|c|}
\hline & $\begin{array}{c}\text { Fluency } \\
\text { and } \\
\text { Coherence }\end{array}$ & $\begin{array}{c}\text { Lexical } \\
\text { Resource }\end{array}$ & $\begin{array}{c}\text { Grammatical } \\
\text { Range and } \\
\text { Accuracy }\end{array}$ & Pronunciation & $\begin{array}{c}\text { Poster } \\
\text { Design }\end{array}$ & $\begin{array}{c}\text { BAND } \\
\text { SCORE }\end{array}$ \\
\hline $\begin{array}{l}\text { Pre-test } \\
\text { average } \\
\text { scores }\end{array}$ & 4.0 & 4.0 & 4.0 & 4.0 & 6.0 & 4.0 \\
\hline
\end{tabular}




\begin{tabular}{|l|l|l|l|l|l|l|}
\hline $\begin{array}{l}\text { Post-test } \\
\text { average } \\
\text { scores }\end{array}$ & 7.0 & 7.0 & 7.0 & 6.0 & 8.0 & 7.0 \\
\hline
\end{tabular}

For each of the scoring criteria, students made significant progress. Specifically, students got much bigger changes in the Lexical Resource criteria as well as Grammatical Range and Accuracy criteria with an average score of 7.0 and 7.0 respectively in the post-test, which were 3.0 points higher than the results in the pre-test. Furthermore, they still had many difficulties with the Fluency and Coherence criteria and Pronunciation because the average score in the post-test for these criterion only increased to mark 7.0 and 6.0 respectively, compared to 4.0 in the pre-test. We also found that the participants' scores for poster design was the highest in both the pre-test and post-test at 6.0 and 8.0 respectively.

To demonstrate the effectiveness of using posters designing activities in students' speaking performance, we also compared the speaking results of the participants in the pretest and post-test as can be seen in Figure 3.

\section{PRE-TEST}

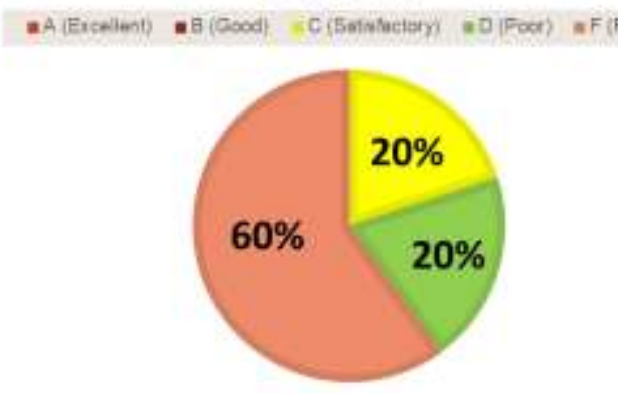

POST-TEST

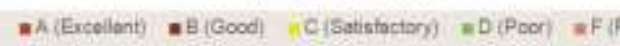

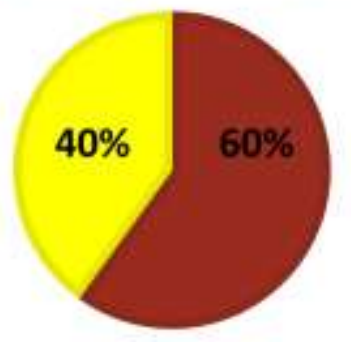

Figure 3. Results of grading student's speaking performance in the pre and post-test

Figure 3 indicates that no one in the class got Grade A-Excellent and Grade B-Good in the pre-test. Meanwhile, there were $60 \%$ students gaining Grade F-Failure and only one fifth got Grade B-Good and another one fifth got Grade C-Satisfactory.

By contrast, the number of students who got Grade B and Grade C in the post-test accounted for $60 \%$ and $40 \%$, respectively. Although no student could get Grade A, there were no students getting Grade D and Grade F.

Coming to the poster design, we compared the first poster and the last poster to reveal that students made a lot of positive changes in organizing the appearance for their posters. Gradually, the students became more confident and creative in both designing posters and speaking.
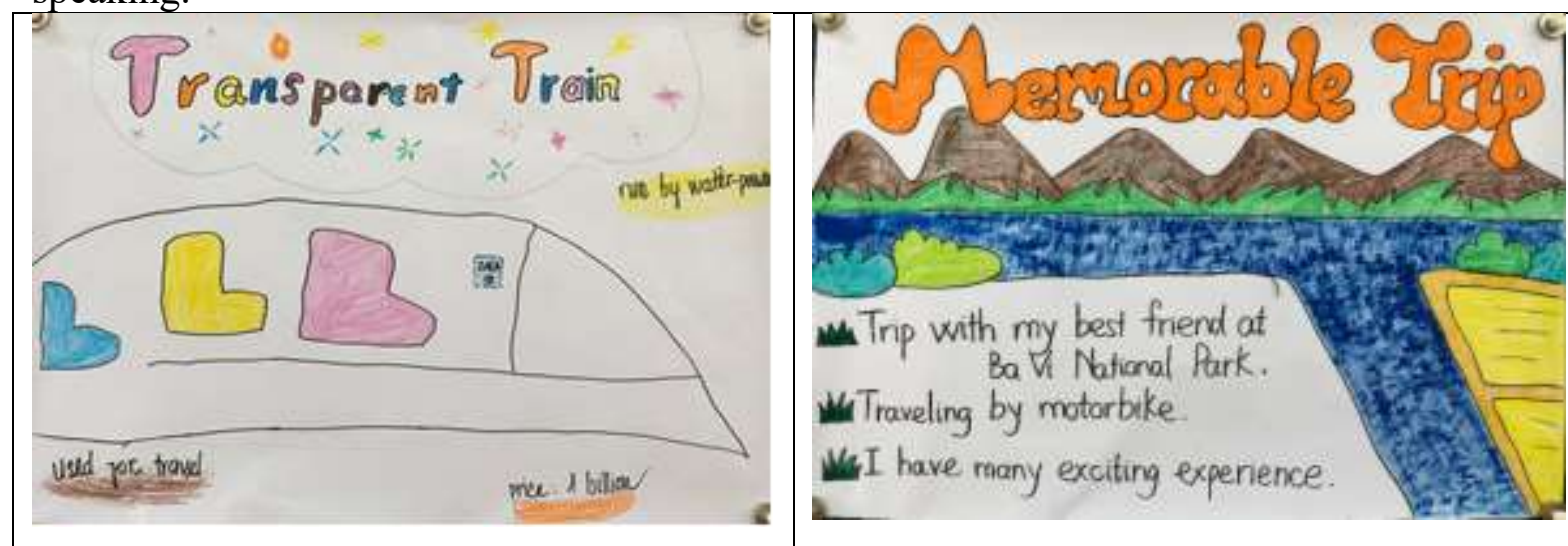


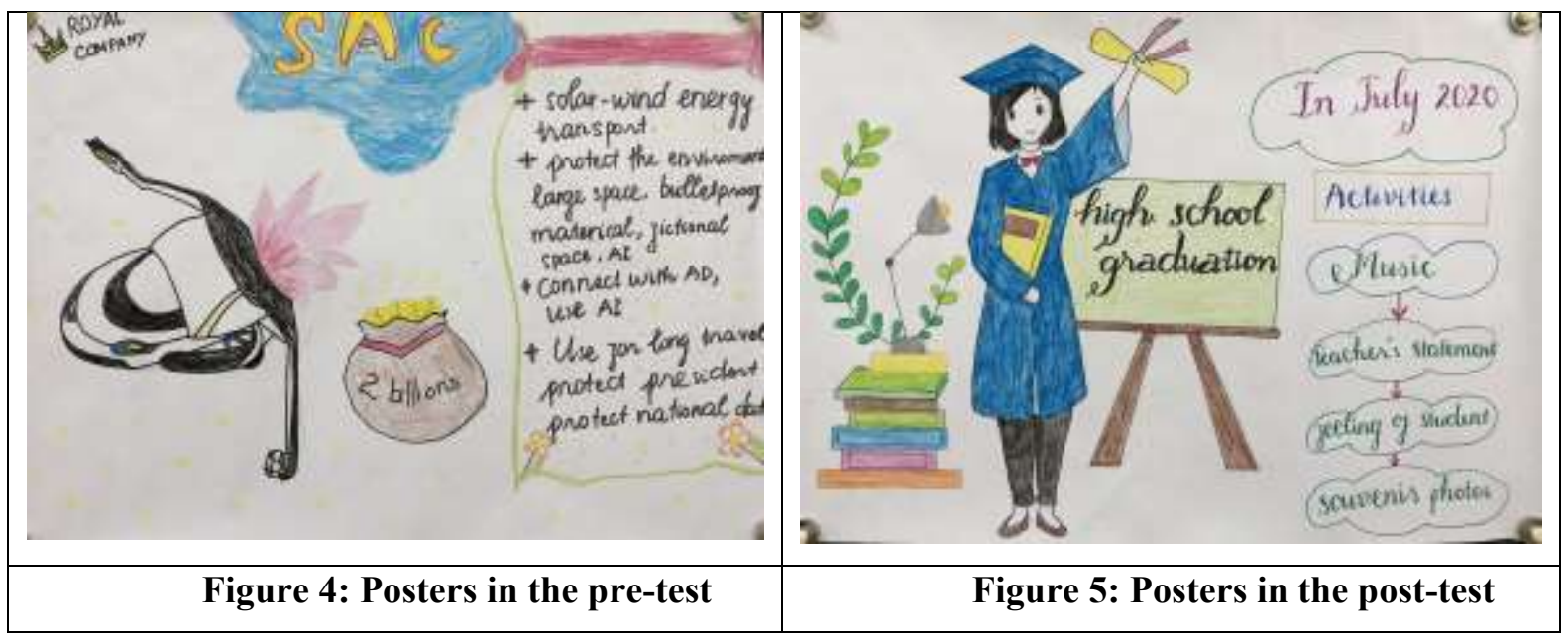

\subsection{Classroom Observation}

The students who are in experimental process attended six speaking lessons. The topic for each lesson was based on the content of their textbook (Life Pre- Intermediate). In each lesson, the researcher provided learners vocabulary related to the topics, require them to work in groups of 5 members or work individually to make posters and then speak based on the posters designed.

While observing the speaking, we found that their speaking performance has improved significantly over time in terms of vocabulary, grammar, pronunciation, fluency and poster design. Regarding vocabulary, students showed how their vocabulary related to the speaking topics increased by using synonyms or antonyms. Relating to grammar, the researchers could see that the frequency of grammatical mistakes decreased obviously after receiving peer check and teacher's correction; students recognized the mistakes and corrected them on the drafts before accomplishing their posters as well as in their speaking performance. In addition, students' pronunciation and speed also improved clearly; they could pronounce more naturally with good intonation, stress and less hesitation in long sentences than they did in the beginning.

In addition, the results from the analysis of the observation checklists show that students' interaction, attitude during the lessons and the atmosphere in the class was always positive. Specifically, in the process of working with posters, the students were highly collaborative with the researcher as they understood and followed the instructions of the researcher and asked questions to get clear explanation. They did not chat with their mates or played their mobile phones. Also, these students took part in team work or discussed about drawing mind maps actively. The students seemed happy and interested in the lessons, which made the classroom atmosphere exciting.

From all the analysis above, it can be noticed that when speaking based on posters designing, students were given opportunities to develop ideas, draw colorful pictures and improve their speaking performance.

\subsection{Students' feedback on speaking through posters designing activities}

The results of the feedback questionnaires for students show that most of the students are interested in learning English speaking through using posters designing activities. They would like to use this method not only to learn English speaking but also to improve other aspects in learning the English language.

All the surveyed students (100\%) like speaking English through posters designing activities and nearly all of them (95\%) agreed that posters can help improve their speaking performance. It means that their attitude toward speaking with posters designing activities is highly positive. 
Regarding different aspects of speaking performance, the students' responses were also very optimistic.

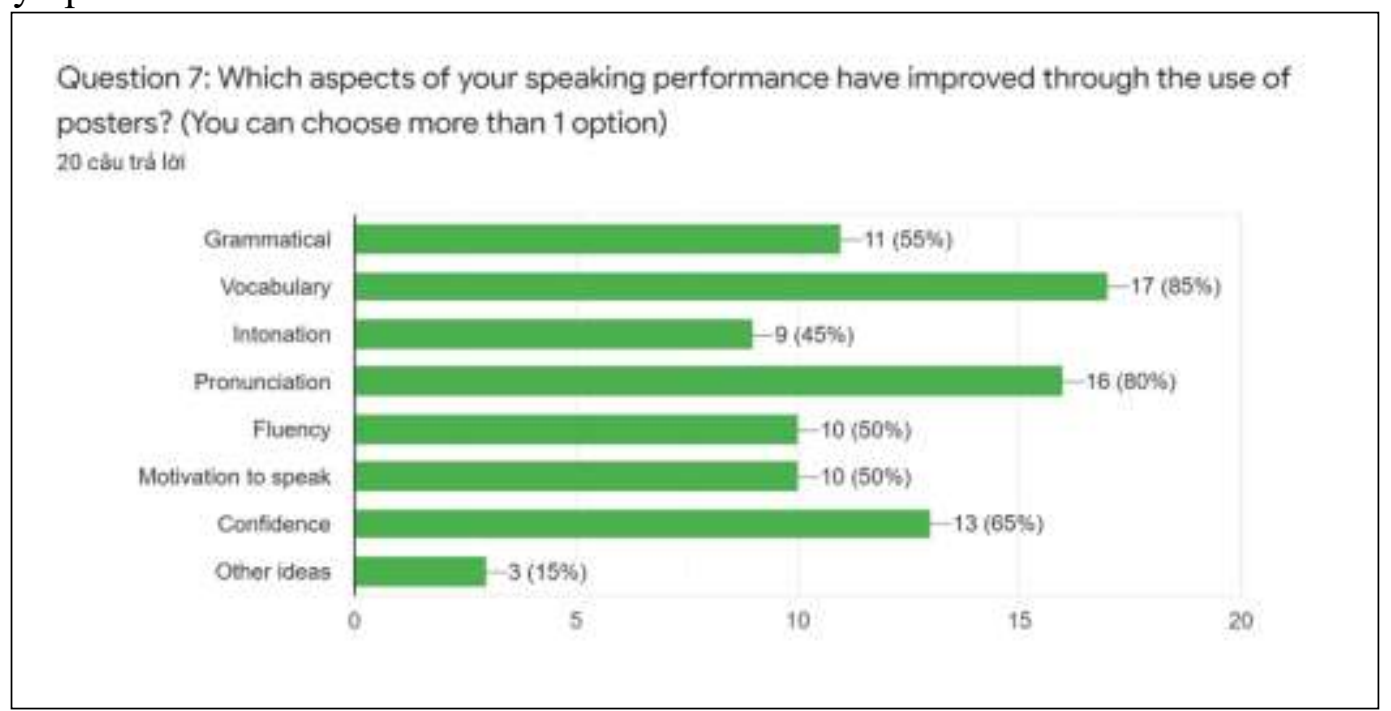

Figure 6: The proportion of speaking performance have improved through posters

As can be seen from Figure 6, many aspects of speaking performance have improved through the use of posters. Vocabulary was a speaking aspect that has improved among most of the students $(85 \%)$. In other words, students could activate more vocabulary through posters than normal learning activities. Pronunciation was another aspect that has improved ( $80 \%$ of the students). The researchers found out that the students pronounced better and more clearly. Confidence stood in the third position with $65 \%$ of the students who confirmed that they were more active and talkative in speaking lessons; some of them did not feel shy when speaking in front of the whole class. 55\% of the students believed that their grammar has improved after making posters with instructions of the teacher and the researchers. Half of students agreed that their fluency as well as motivation to speak has improved. $45 \%$ of the students stated that their intonation has improved when they took part in speaking based on posters design.

\section{CONCLUSION}

\subsection{Main Findings}

After conducting the survey and the experiment, analyzing and discussing the results, the researchers could summarize the main findings as below:

One, the level of speaking performance of the first-year non-English majors was not good in general; they still had problems with grammar, pronunciation as well as fluency.

Two, in the experiment process, the researchers recognized that the students responded positively toward the use of posters in speaking classes and students became more interested, motivated, active, and creative in learning by using posters which were designed by themselves.

Three, the use of posters designing activities in speaking lessons could improve students' speaking performance. Moreover, almost all of the students appreciated the effectiveness of posters designing activities to enhance their English speaking performance. Actually, $95 \%$ of the students claimed that posters designing activities were effective in improving their speaking performance. In addition, most of the English non-majors have a positive attitude toward posters designing activities, and they listed many aspects of speaking performance which have improved through the use of posters based on this method. 
In fact, the present research has shown that despite recent changes in teaching English speaking, speaking based on posters designing activities plays a significant role in improving and enhancing English speaking performance for non-English majors. Comparing to the beginning of the study, the participants have made many more considerable improvement in their speaking performance in all aspects of vocabulary, grammar, pronunciation, fluency and posters design. The students have become more confident and interested in speaking as they have employed posters in their speaking tasks.

\subsection{Recommendations}

Through the post-questionnaire, the participants proposed some solutions to enhance the use of posters in improving speaking performance in speaking lessons. Teachers who teach English speaking skills should organize posters designing activities frequently in lessons, especially speaking ones as well as apply different speaking activities based on posters designed in lessons, which makes the students interested in the English lessons. Moreover, the teachers should organize the speaking lessons with posters designing activities as a competition and give several small presents in order to encourage students to get involved in speaking activities actively and enthusiastically. Besides, the teachers ought to recommend their students to search what they want to draw on the Internet if they are not good at drawing or they have no idea how to design their posters. They should also encourage students to explore their painting styles as well as learn how to draw in a more vivid and eyecatching manner.

In addition, to make this method more effective, students should actively take part in poster designing activities not only in presentation but also in other activities such as debating, describling, retelling, giving and supporting for opinions in speaking class. Secondly, learners should train their painting ability to join posters designing activities more actively. In addition, encouraging learners to work with their friends to design their posters in speaking class is also a good way for participants to motivate their confidence in speaking because they can exchange their ideas in designing progress; therefore, learners can deeply understand the speaking topic with varied ideas.

\subsection{Conclusion}

The current research was conducted to improve English speaking performance for non-English majors by organizing activities for students to design posters and speaking based on the posters that have been designed. The research results show that posters designing activities can be considered an effective and interesting way of teaching speaking for the purpose of enhancing students' speaking performance. In addition, the students' attitudes towards the use of posters designing activities are positive. The majority of them asserted that they feel happy and joyful with the method. They also stated several reasons for their agreement with the use of posters, which are creating them the confidence and willingness to speak; enhancing their ideas and providing them with the grammatical structures, vocabulary, and interest for generating ideas. With all of these benefits of using posters designing activities to enhance English non-majors speaking performance at Thai Nguyen University of Education, the researchers highly recommend that this method should be made an integral part of not only speaking courses but also other subjects. 


\section{REFERENCES}

Brown, H D. (1994). Principles of Language Learning and Teaching ( ${ }^{\text {rd }}$ ed.). upper Saddle River, NJ: Prentice Hall.

Brown, H D. (2004). Language Assessment Principles and Classroom Practices. New York: Pearson Education Inc.

Bygate, M. (1987). Speaking. Oxford. Oxford University Press

Chaney, A. L., and Burke, T. L. (1998). Teaching Oral Communication in Grade K-8. Boston: Allyn \& Bacon, Inc.

Chau V. D. (2017). Improving English speaking skills for English majored students through poster-making activities: A tool of multiple intelligences. Journal of Inquiry into Languages and Cultures 1 (1), 1-12.

Farisha A. B., \& Reskiwati, A. (2014). Using Practice Posters to Improve Students'speaking skill. Exposure Journal, 3(1), 29-53.

Hemerka, V. (2009). Low Speaking Performance in Learners of English [Bachlore Thesis, Masaryk University]. https://is.muni.cz/th/b343q/Low Speaking Performance BC Thesis.pdf

Macmillan Dictionary. https://www.macmillandictionaryblog.com/author/macmillannewsletter

Nunan, D. (1987). Language Teaching Methodology: A Textbook for Teacher. New York: Prentice Hall.

Ozmen, E. (1990). Up, Up With Posters. English Teaching Forum, 44 (1), 67-78.

Rahmah, S. (2014). The effectiveness of poster presentation in teaching speakinng to the seventh grades of MTs Nw Ketangga in the school year 2013-2014 [Bachlore Thesis, Hamzanwadi Selong College of Teacher Training and Education]. https://www.academia.edu/9614417/the_effectivness_of_poster_presentation_in_teac hing_speaking_to_the_seventh_grades_of_MTS_NW_Ketangga_in_the_school_year 2013_2014_a_thesis_study_program_of_english_language_education_department_o f_language_and_art_education_stkip_hamzanwadi_selong_2014.

Reilly, P. 2007. Using practice posters to address EFL challenges. English Teaching Forum 45 (3), 24-29.

Sudjana, N. (1989). Dasar-Dasar Proses Belajar Mengajar. Bandung: Sinar Baru.

Ulva, S. (2019). The Use of Poster Media in Improving Students' Speaking Ability (A case Study at MTsN 2 Banda Aceh) (Doctoral dissertation, Tarbiyah).

Widdowson, H. G. Learning Purpose and Language Use. Oxford: Oxford University Press.

\section{AUTHORS' BIO}

Tran Thi Yen is a lecturer of English from Thai Nguyen University of Education, a teacher training institution in the northern mountainous area of Vietnam. She is interested in English teaching methodologies and teaching linguistic areas.

Tran Thi Minh Hang is a student whose major is English at Thai Nguyen University of Education. She is passionate about learning languages and assisting others in finding out effective methods in studying English. 